\title{
How Legal Protection of Women in Home Workers Improving Family Welfare?
}

\author{
Dewi Sulistianingsih ${ }^{1 *}$, Muhammad Shidqon Prabowo ${ }^{2}$, Martitah \\ Martitah $^{3}$ \\ 1,3 Faculty of Law, Universitas Negeri Semarang, Indonesia \\ 1 Faculty of Law, Universitas Wahid Hasyim, Semarang, Indonesia \\ Corresponding Author: dewisulistianingsih21@mail.unnes.ac.id
}

Abstract: Homeworkers are work that is done at home either on the basis of orders from others or doing on the basis of oneself. This type of work is referred to as informal workers, which is clearly difficult to obtain legal protection. Labor laws in Indonesia provide legal protection for both formal and informal workers, but the practice for informal workers is difficult to obtain legal protection. This program aims to describe and analyze the legal protections of women homeworkers in Semarang City in their efforts to make their families prosperous. This program uses socialization methods, interviews, observation and documentation. This program is conducted in the city of Semarang. The results of this program can be seen that the protection of homeworkers is still very minimal, especially for independent homeworkers. The implementation of statutory regulations has not been optimal, especially in manpower laws. The government is still not optimal in providing legal protection for informal workers, especially for homeworkers. Low wages, long working hours and the absence of health insurance are among the elements that homeworkers need to improve and increase in their efforts to make their families welfare. In the effort to achieve welfare for homeworkers' families, it is necessary to carry out supervision and guidance for homeworkers. Supervision and guidance can be carried out by the central government, local governments, non-governmental organizations, the academic community, observers of labor.

Keywords: Homeworker; Well-being; Legal Protection; Women Protection 


\section{A. Introduction}

Work is something that is usually done by every human being. Various reasons and human goals work. The reason most often used why humans work is to get income even though this reason is not the main thing for every human being. Many things are reasons for humans to do their jobs. Work as a means to express and develop self-potential. This excuse is used for people who make work as suggestions for self-actualization.

Work as a means to worship and serve others. This reason is a reason for people who are more inclined towards immaterial rather than material. Working as homeworkers is also done as a form of self-improvement so that they are able to compete with other workers. Work in this regard is done to expand the network and prepare to become entrepreneurs. The homeworker will work under the orders of the employer, after which he will have the confidence to start a new business or become an independent entrepreneur. Homework is an activity carried out by families, mostly women, from generation to generation, with grandmothers, mothers and daughters involved in homework. Homeworkers are carried out in the worker's own home or it can also be done at the employer's house.

However, most homeworkers carry out their activities at home by themselves. Generally, domestic workers consist of two, namely independent workers and subcontracted workers. Independent workers are not tied to an employer or employer, while subcontracted workers are bound by a contract with the employer. Independent workers do work according to their own concept and are mostly done in their own homes, while subcontracted workers are done at home or at the employer's house. The homeworker carries out his work in his own house or at another place of his choosing which is not the place of the employer.

The work system by bringing work to workers' homes or what is called the putting out system applies in areas that have a potential workforce, especially women, and there is little or no work that they can do. The putting out system is a production system implemented by workers (usually women workers with the aim of earning additional income from outside the home) in each worker's home. The characteristic of this job is that it is in the informal sector, the relationship between the employer and the worker is a subordinate relationship in which the worker only has the obligation to accept what has been determined by the employer without having the right to a balanced proposal.The characteristics of the Putting out System are the place where the worker is the house of the worker, the nature of the worker is voluntary, the work relationship tends to be through an oral and informal agreement, 
and the homeworker does not have the authority to determine the buyer and marketing of the product. ${ }^{1}$ Homeworkers can simply be defined as workers from a company who carry out production activities outside the company environment (at home or at a community gathering place). Although in fact the work can be done within the company environment (by formal workers), some companies prefer to transfer the work to homeworkers so that they do not need to recruit too many formal workers as it is seen that it will increase production costs. Some examples of work that homeworkers often do include food processing; garment product finishing; or the packaging process. ${ }^{2}$

Basically, the relationship between entrepreneurs and homeworkers is a cooperative relationship in which the cooperation is to produce a required product and service. Workers have a role or duty to process products owned by employers, whether in the form of raw materials or semi-finished materials, which then turn them into goods and services needed.

The characteristics of homework, home based production include: (1) it does not require high skills; (2) can be done at home without having to leave her daily duties as a housewife; (3) can make money in a short time (daily weekly); (4). capital is not large; and (5) Performed by women. ${ }^{3}$ The majority of homeworkers are carried out by women, but not a few homeworkers are carried out by men. The homeworkers that are mostly done by men are jobs that are more skilled, such as workshops, washing cars or motorbikes, electricity, etc.

Apart from these characteristics of homeworkers there are various types of work that can be done. All types of homeworkers enter into the informal sector which generally does not require very high formal education qualifications. Nonetheless, it does not mean that homework is easy to do as there will still be competition from other homeworkers. Homeworkers make an important contribution to family well-being. The family economy will prosper when the needs of the family can be met. Fulfilment of this need is a form and indicator that the family is said to be prosperous.

In Indonesia, homeworkers are often known as piece workers who do their work at home and are paid based on the unit wage they earn. Wages are one of the biggest challenges for homeworkers. Low-income challenges (low

1 Agusmidah, A. (2018, October). Hak Ekonomi Perempuan: Pekerja Rumahan dalam Jangkauan Undang-Undang Ketenagakerjaan. In Talenta Conference Series: Local Wisdom, Social, and Arts (LWSA) (Vol. 1, No. 1, pp. 001-007).

2 Edry, R. P., \& Musyafah, A. A. (2019). Pemenuhan Hak-hak Pekerja Rumahan Dalam Pola Usaha Kemitraan Antara Perusahaan Dengan Pekerja Rumahan. Jurnal Pembangunan Hukum Indonesia, 1(2), 266-280.

3 Sofiani, T. (2010). Eksistensi perempuan pekerja rumahan dalam konstelasi relasi gender. Jurnal Muwazah [internet]. [Diunduh pada 2017 Desember 18], 2(1), 197-2014. 
wages) and unstable work orders. Orders may not be available every day. Some see limited space at home due to homework as a challenge. This paper describes the homeworkers in their efforts to improve protection and welfare. The implementation of the Manpower Law in Indonesia is difficult to provide protection for informal workers such as homeworkers. Lack of adequate health insurance, long working hours, etc. Welfare is a big question because there are still many homeworkers who earn not big wages.

\section{B. Method}

This program uses the socialization method. The socialization method is carried out with the aim of providing knowledge, insight and understanding of the meaning of legal protection for domestic workers in their efforts to improve the family economy. The socialization was carried out at the AsShodiqiyah Islamic Boarding School in Semarang City with several domestic workers who attended the socialization. This program also uses interview and observation methods. Interviews, observation, and documentation were carried out after the socialization was carried out, with the aim of obtaining a complete picture of the portrait of domestic workers in the city of Semarang.

The location of this program is in Semarang City with the basic reason that Semarang City has a high number of workers in Central Java Province. Semarang City as the capital city of Central Java is the most densely populated city and the number of workers is quite high compared to other cities in Central Java Province.

\section{Result and Discussion}

Homeworkers consist of two types of workers. First, independent homeworkers. This type of worker takes risks independently. Buying own raw materials, equipment, production costs, selling the products yourself. Generally independent homeworkers do not employ other people but employ family members themselves. Second, homeworkers on a sub-contract basis. Generally. this type of homeworker has an agreement with the company. Homeworkers are provided with raw materials and paid per piece. Homeworkers get wages for the results of their work. This wage is given by the company that provided the job.

Unlike workers in factories, homeworkers are paid based on work targets, such as the number of products they are able to produce (units / pieces), not based on length of work or working hours, without taking into account the provision of additional tools and materials that have to be

4 Indonesian Journal of Advocacy and Legal Services, Vol. 3 No. 1 (2021) 
prepared by homeworkers. Wages are obtained directly from the company or employer where they take goods to be produced. Usually, the homeworkers accept jobs from certain companies or intermediaries as shown on Table 1.

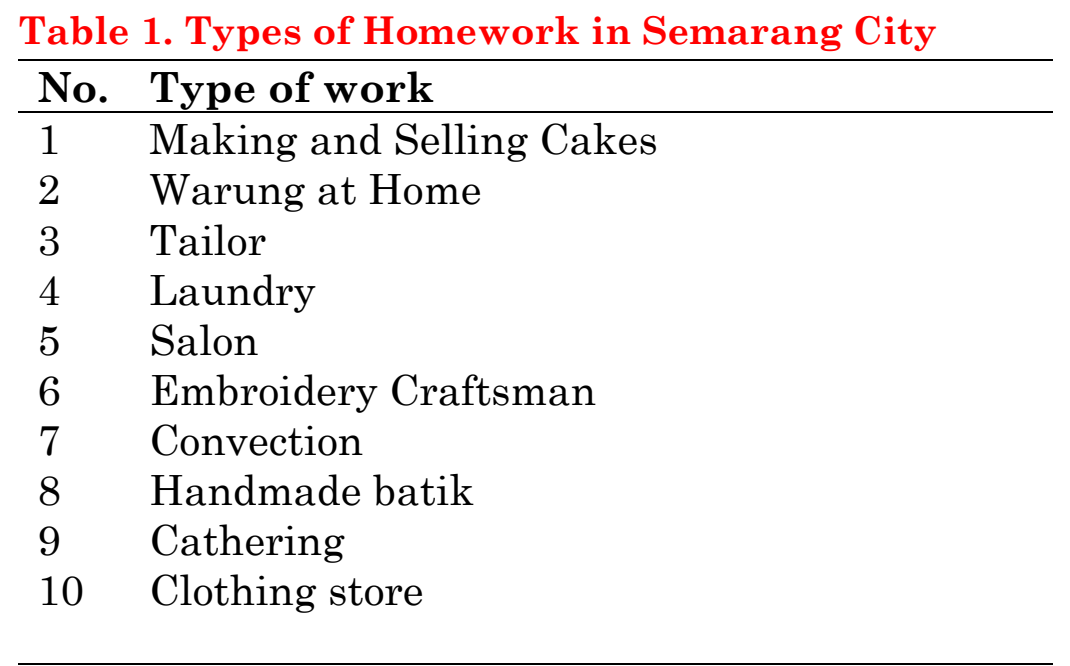

Source: Personal document by Authors

Homeworkers who are self-employed or subcontracted have similarities in the barriers to carrying out their work. These obstacles include: (1) Lack of capital, especially for the independent homeworkers; (2) Limited time. Generally, homeworkers find it difficult to divide their time, in contrast to formal workers who have clear working hours; (3) financial management which is relatively not well controlled.

Many home-based workers do domestic work during the day and work as homeworkers for long hours at night, which can lead to fatigue and eye strain. Some homeworkers generate dust or use hazardous chemicals. However, often the workspace and family room are not separate. This can harm both homeworkers and other family members, including children. ${ }^{4}$ This is a portrait of homeworkers in Indonesia who have unspecified wages, unspecified working hours, and in the absence of adequate medical benefits.

\section{Homeworkers: How to Protect Them}

Work becomes an option for workers when workers have good abilities and skills. Workers who do not have good abilities and skills, then work becomes a challenge for him. Before a prospective worker gets the job he wants, you should prepare yourself to be fit for the job. The circumstances and conditions of a prospective worker also determine a good job for him to

4 Dewanti, N. A. Y., Sulistiyani, S., Setyaningsih, Y., \& Jayanti, S. (2018). Faktor Risiko Bahaya Tempat Kerja dan Lingkungan Rumah terhadap Kesehatan Home-based Worker di Kota Semarang. Jurnal Kesehatan Lingkungan Indonesia, 17(1), 52-58. 
do. Becoming a homeworker may not be an option for homeworkers, but it is a provision that must be taken because of the circumstances and conditions that require him to remain at home.

The International Labor Organization (ILO) regulates this in Convention No.177 on Home Workers in 1966. The ILO notes that the special conditions of homework which characterize homeworkers are preferable for this reason the ILO establishes the application of the convention. and recommendations for homeworkers and for assisting them with working standards that take into account the characteristics of homeworkers.

In Indonesia, there is no statutory regulation that regulates work based at home/homework. Indonesia to date has also not ratified ILO Convention No. 177 concerning Homework. Lack of explicit legal recognition of homeworkers as a special category of workers in existing laws and regulations in Indonesia ${ }^{5}$. Homeworkers in Indonesia have not been protected by Labor Law, so they have difficulty obtaining workers rights such as living wages, social security and work accident protection.

Homeworkers need occupational health and safety guarantees as well as fulfillment of work facilities, there is no legal umbrella in force in Indonesia to protect homeworkers, homeworkers unions are needed as access to information and knowledge so as to create a sense of solidarity and reduce job competition, collective contract agreements for employers and work recipients include: distribution of wages that have been minimal, holiday allowances (THR) and sharing of time, rest and leave'.

Homeworkers need regulation so that they receive protection and improve their welfare. He noted the challenges facing homeworkers today include being prone to discrimination, minimal protection and wages. The state has the duty to provide protection and welfare guarantees for the people as stated in the constitution of the Republic of Indonesia. These efforts need to be carried out by the state (in this case the government). The government cannot eliminate the responsibility for supervision and protection for homeworkers. The government does not only provide protection but also needs to carry out supervision especially for employers who assign work to homeworkers.

5 Solechan, S. (2018). Perlindungan Homeworker Yang Berkerja Secara Putting Out System. Administrative Law \& Governance Journal, 1(4), 386-390.

6 Utami, T., Amrina, N., \& Maimunah, M. (2019). Perlindungan Hukum Bagi Pekerja Rumahan Yang Bekerja Secara Putting Out System Melalui Optimalisasi Peran Badan Usaha Milik Desa. Administrative Law \& Governance Journal, 2(2), 365 379. https://doi.org/10.14710/alj.v2i2.365 - 379

6 Indonesian Journal of Advocacy and Legal Services, Vol. 3 No. 1 (2021) 


\section{Welfare for Homeworkers}

The ILO Conventions have defined homeworkers in the formulation of Article 1 which basically explains that homeworkers must meet three criteria, namely Convention No. 177 in Article 1 defines homeworkers in 3 elements, namely: (1). Specified work means work to be carried out by homeworkers in their home or in a place that has been chosen by the homeworker outside the place of the employer; (2). Wages, means that the work carried out by homeworkers is rewarded with a certain wage which is paid within a certain period of time; (3). The level of subordination, which means that homeworkers produce a product or service according to what the employer determines, regardless of the supply of equipment, raw materials or tools and those used to achieve the production process.

Homeworkers emerged because the competitiveness between companies was increasing. In the context of efficiency, companies use homeworkers to support production activities. The work that is done at home becomes income for homeworkers such as persons with disabilities who have difficulty going outside the home. The women homeworkers are mostly empowered by the company to do work according to the company orders. These women become homeworkers because they do this work in between while carrying out their duties and obligations as housewives.

Women have the role of housewives which is an absolute role that cannot be eliminated in our patriarchal culture of society. Even indirectly every woman will definitely become a housewife and have a motherly spirit. Therefore, when women work, what happens is they continue to do their role as housewives. ${ }^{7}$

Efforts to make their life prosperous, everyone is guided by the fact that if we work hard and hard for the sake of a family waiting for results at home, that is, having a dream that the wages / salaries from their work achievements can meet all the necessities of life for their families without any shortcomings.

Welfare is a condition where a person can fulfill his basic needs such as the need for food, clothing, shelter, clean drinking water and the opportunity to continue his education and have an adequate job that can support the quality of his life so that he can live free from poverty, ignorance, fear, or worry because his life is safe, peaceful, both physically and mentally ${ }^{8}$. This can also be the reason why workers do home work, the main reason being to achieve welfare for their families. There are many ways for workers to

\footnotetext{
7 Hidayati, N. (2015). Beban ganda perempuan bekerja (antara domestik dan publik). Jurnal Muwazah, 7(2), 108-119.

8 Fahrudin, Adi. (2012). Pengantar Kesejahteraan Sosial. Bandung: Refika Aditama.
} 
prosper, as well as homeworkers. They do work at home for their own reasons, including, homework is done as a side job, or as a job that is done simultaneously doing work as a housewife.

In Semarang City itself, the number of people who do not work is still quite a lot. especially since the covid 19 pandemic. In general, the impact of unemployment on family welfare is very influential. Decreased income makes it difficult to meet family needs.

The Central of Statistics for the City of Semarang noted that in the city of Semarang there were still quite a lot of unemployed people.

Table 2 Total Semarang City Workforce

\begin{tabular}{ccclcc}
\hline No. & Year & Work & $\begin{array}{c}\text { Open } \\
\text { Unemployment }\end{array}$ & $\begin{array}{c}\text { Total } \\
\text { Force } \\
\text { Work }\end{array}$ & \\
\cline { 1 - 4 } 1 & 2017 & 899,796 & 63,700 & 963,496 & \\
2 & 2018 & 872,827 & 48,724 & 921,551 & Source: BPS \\
3 & 2019 & 907,037 & 43,198 & 951,135 & Semarang City \\
\hline
\end{tabular}

Homeworkers carry out their work with the aim of increasing the economic income of the family, in order to realize family welfare. This is one of the solutions to improve the family economy. In this case, work as a domestic worker is not an option but a situation where the work can be done under certain conditions.

The condition of a household that is completely deprived will motivate household members to work to increase income. Low family income can lead to reduced family welfare ${ }^{9}$. Family welfare is the main objective of why homeworkers do such work. The wages earned are expected to be able to provide or improve family welfare.

Law Number 52 of 2009, regarding population development and family development Article 1 paragraph 11 defines family welfare as: "the condition of a family that has resilience and resilience and contains physical and material abilities to live independently and develop themselves and their families to live in harmony in improving well-being of inner and outer happiness.

One of the ways homeworkers provide for the welfare of their families is by increasing the income (wages) from their work. It is an issue whether

9 Telaumbanua, Marietta Marlina; Nugraheni, Mutiara. Peran Ibu Rumah Tangga Dalam Meningkatkan Kesejahteraan Keluarga. Sosio Informa, [S.l.], v. 4, n. 2, nov. 2018. ISSN 2502-7913. Available at: $<$ https://ejournal.kemsos.go.id/index.php/Sosioinforma/article/view/1474>. Date accessed: 28 aug. 2020. doi:https://doi.org/10.33007/inf.v4i2.1474.

8 Indonesian Journal of Advocacy and Legal Services, Vol. 3 No. 1 (2021) 
the wages earned by homeworkers are sufficient for the needs of the family. In fact, not. and this is a record for the government and for policy makers to be able to pay attention to the welfare of domestic workers. The absence of a standard wage means that the wages earned by homeworkers do not meet the standards for the welfare of the family.

Wages are indeed things that need to be considered in employment, because the goal of working people is to get wages that will be used to meet the needs of their lives and their families..$^{10}$ With these various problems, homeworkers are in a very vulnerable and poor position. So that special measures are needed to promote the protection and fulfillment of the basic rights of homeworkers as workers.

\section{Conclusion}

This study concluded that, homeworkers are protected by several laws and regulations in Indonesia, however they have not been able to significantly protect homeworkers. The labor law has not been able to provide maximum protection to homeworkers. ILO Home Work Convention (1996), No. 177 is one of the legal instruments capable of providing protection for home workers, but until now Indonesia has not ratified the convention. Some of the problems faced by homeworkers to date have not been resolved properly such as unstandardized wages, very long working hours, absence of occupational health and safety protection. There are several efforts that the government can do, such as raising awareness to the whole community about the existence of homeworkers. Because many people do not know what the conditions are faced by homeworkers. The government needs to make the right strategy to increase the role and existence of homeworkers, among others through increasing skills, capital assistance by looking at the market potential so that the programs rolled out by the government are right on target.

\section{E. Acknowledgments}

This article was made possible because of the funding from the Faculty of Law, Semarang State University with the Community Service program. Thank you to Pondok Pesantren As-Shhodiqiyah Semarang, who have been willing to lend a place to hold the socialization of this program.

10 Dewi, S. L., \& Sonhaji, B. I. (2017). Penerapan Prinsip Non Diskriminasi dan Kesetaraan dalam Pengupahan Bagi Pekerja/buruh di Kabupaten Kendal. Diponegoro Law Journal, 6(1), 1-21. 


\section{F. Declaration of Conflicting Interests}

The authors state that there is no potential conflict of interest in the research, authorship, and/or publication of this article.

\section{G. Funding}

Universitas Negeri Semarang by Faculty of Law Research and Community Services Grants.

\section{H. References}

Agusmidah, A. (2018). Hak Ekonomi Perempuan: Pekerja Rumahan dalam Jangkauan Undang-Undang Ketenagakerjaan. In Talenta Conference Series: Local Wisdom, Social, and Arts (LWSA) (Vol. 1, No. 1, pp. 001007).

Dewi, S. L., \& Sonhaji, S., \& Ispriyarso, B. (2017). Penerapan Prinsip Non Diskriminasi dan Kesetaraan dalam Pengupahan Bagi Pekerja/buruh di Kabupaten Kendal. Diponegoro Law Journal, 6(1), 1-21. https://ejournal3.undip.ac.id/index.php/dlr/article/view/15675/15157.

Dewanti, N. A. Y., Sulistiyani, S., Setyaningsih, Y., \& Jayanti, S. (2018). Faktor Risiko Bahaya Tempat Kerja dan Lingkungan Rumah terhadap Kesehatan Home-based Worker di Kota Semarang. Jurnal Kesehatan Lingkungan Indonesia, 17(1),

52-58. https://doi.org/10.14710/jkli.17.1.52-58.

Edry, R. P., \& Musyafah, A. A. (2019). Pemenuhan Hak-hak Pekerja Rumahan Dalam Pola Usaha Kemitraan Antara Perusahaan Dengan Pekerja Rumahan. Jurnal Pembangunan Hukum Indonesia, 1(2), 266280. https://doi.org/10.14710/jphi.v1i2.266-280

Hidayati, N. (2016). Beban Ganda Perempuan Bekerja (Antara Domestik dan Publik). MUWAZAH: Jurnal Kajian Gender, 7(2), 108-119. http://ejournal.iainpekalongan.ac.id/index.php/Muwazah/article/view/516

Sofiani, T. (2010). Eksistensi perempuan pekerja rumahan dalam konstelasi relasi gender. MUWAZAH: Jurnal Kajian Gender, 2(1), 197-2014. http://e-

journal.iainpekalongan.ac.id/index.php/Muwazah/article/view/17.

Solechan, S. (2018). Perlindungan Homeworker Yang Berkerja Secara Putting Out System. Administrative Law \& Governance Journal, 1(4), 386-390. https://doi.org/10.14710/alj.v1i4.386 - 390

Telaumbanua, M. M., \& Nugraheni, M (2018). Peran Ibu Rumah Tangga Dalam Meningkatkan Kesejahteraan Keluarga. Sosio Informa, 4(2), 418-436. https://doi.org/10.33007/inf.v4i2.1474. 
Utami, T., Amrina, N., \& Maimunah, M. (2019). Perlindungan Hukum Bagi Pekerja Rumahan Yang Bekerja Secara Putting Out System Melalui Optimalisasi Peran Badan Usaha Milik Desa. Administrative Law \& Governance Journal, 2(2), 365 379. https://doi.org/10.14710/alj.v2i2.365 - 379. 
D. Sulistianingsih, et.al

\section{ABOUT AUTHORS}

Dr. Dewi Sulistianingsih, S.H., M.H., is lecturer at Department of Private and Commercial Law, Universitas Negeri Semarang, Indonesia. She is also a Director of Research and Community Services Unit Faculty of Law, Universitas Negeri Semarang and Editor in Chief Journal of Private and Commercial Law and Jurnal Pengabdian Hukum Indonesia. Some of her recent publications such as Out of Court Intellectual Property Right Dispute Resolution ( $1^{\text {st }}$ Borobudur Conference on Humanities, Economics, and Sociel Sciences, 2020), Fungsi Dan Kedudukan Perjanjian Berbentuk Pactum De Compromittendo Dalam Sengketa Hak Kekayaan Intelektual (Jurnal MetaYuridis, 2020), and Problematik Dan Karakteristik Penyelesaian Sengketa Kekayaan Intelektual Melalui Badan Arbitrase Nasional Indonesia (Qistie, 2019).

Dr. Muhammad Shidqon Prabowo, S.H., M.H., is lecturer at Faculty of Law Universitas Wahid Hasyim (UNWAHAS), Semarang Indonesia. His research interests are concerning Good Governance, Sharia Economic Law, and Legal Protection.

Prof. Martitah, M.Hum., is lecturer at Department of Administrative and Constitutional Law Universitas Negeri Semarang, Indonesia. Her expertise is concerning to Constitutional Law. 